\title{
Toxigenic Profiling of Enterotoxin-Producing Bacillus cereus Isolated from Marketed Raw Chicken Meat and Human Subjects by Triplex and Multiplex PCR
}

\author{
A.P. Suthar ${ }^{1}$, R. Kumar ${ }^{*}$, C.V. Savalia ${ }^{1}$, N.M. Patel ${ }^{1}$ and I.H. Kalyani ${ }^{2}$ \\ ${ }^{1}$ Department of Veterinary Public Health and Epidemiology, College of Veterinary science \& Animal Husbandry, \\ Navsari Agricultural University, Navsari, Gujarat, INDIA \\ ${ }^{2}$ Department of Veterinary Microbiology, College of Veterinary Science E Animal Husbandry, Navsari Agricultural University, \\ Navsari, Gujarat, INDIA \\ "Corresponding author: R Kumar; E-mail: rajeev37171@gmail.com
}

Received: 08 July, 2019

Revised: 08 Oct., 2019

Accepted: 20 Oct., 2019

\begin{abstract}
Bacillus cereus incorporates the most important group of endospore-forming micro organism and can cause emetic and diarrheal food poisoning. A total of $42 \mathrm{~B}$. cereus strains isolated from marketed raw chicken meat and human subjects swab samples were assessed by a triplex and multiplex PCR for the presence of enterotoxin genes. The detection rate of $n h e B, h b l A, h b l D, c y t K$, nheA,CER, hblC and entFM enterotoxin genes among all B. cereus strains was $83.33 \%, 80.95 \%, 69.04 \%, 21.42 \%, 47.61 \%$, $0 \%, 61.90 \%$, and $92.85 \%$ respectively. Enterotoxigenic profiles were determined in enterotoxin-producing strains showed 19 different patterns. The results offer essential information on toxin genes prevalence and toxigenic profiles of $B$. cereus from sources of origin. The present study was taken into consideration about extreme fitness danger for public health and insuring extra ability in difficulty to food safety amongst all B. cereus group members. Also, there may be need for extensive and continuous tracking of food products embracing both emetic toxin and enterotoxin genes.
\end{abstract}

Keywords: Bacillus cereus, enterotoxigenic profiling, PCR, enterotoxin, marketed, Chicken, Meat

Members of the genus Bacillus are well known for their great diversity and widespread distribution in nature $(\mathrm{Oh}$ et al., 2012) and these bacteria Bacillus cereus group ( $B$. cereus sensulato) consisting of the genetically closely related species $B$. cereus, $B$. thuringiensis, B. anthracis, $B$. mycoides, $B$. pseudomycoides, and $B$. weihenstephanensis is widely recognized as the causative agent of food borne illness (Helgason et al., 2000; Kim et al., 2012; Jimenez et al., 2013). Due to its wide distribution in the environment and ability to produce spores, the Gram-positive, rodshaped, opportunistic human pathogen grow well in wide adverse environmental condition, the $\mathrm{pH}$ ranges from 4.5 to 9.3 , with high water activity 0.92 and the temperature ranges for growth from $4^{\circ} \mathrm{C}$ to $50^{\circ} \mathrm{C}$ (Kramer and Gilbert, 1989). Food borne illness resulting from consumption of B. cereus contaminated food may result in diarrheal and emetic type syndromes (Kim et al., 2010; Sandra et al., 2012).
The diarrheal food poisoning is caused by heat-labile protein enterotoxins produced during favorable vegetative growth of $B$. cereus in the small intestine with nonhaemolytic enterotoxin (nhe), enterotoxin FM (entFM), Haemolysin BL $(h b l)$ and cytotoxin $\mathrm{K}(c y t K)$ are of the highest importance and therefore often used for the detection of enterotoxic strains (Kim et al., 2012; Park et al., 2009).

The emetic food poisoning occur due to emetic toxin (cereulide) is a small cyclic peptide (dodecadepsipeptide), which is heat and acid stable, induces swelling of mitochondria in Hep-2 cells, respiratory distress, and occasional loss of consciousness possibly leading to coma and ultimately death of individual (Ladeuze et al., 2011).

How to cite this article: Suthar, A.P., Kumar, R., Savalia, C.V., Patel, N.M and Kalyani, I.H. (2019). Toxigenic profiling of enterotoxin-producing Bacillus cereus isolated from marketed raw chicken meat and human subjects by triplex and multiplex PCR. J. Anim. Res., 9(6): 821-829. 
The heat stable emetic toxin can withstand temperatures of up to $121^{\circ} \mathrm{C}$ for $90 \mathrm{~min}$. The symptoms usually include nausea, vomiting and stomach pain, which occur 1-5 hrs after food ingestion and can easily be misdiagnosed with Staphylococcus aureus food poisoning (Kim et al., 2011; Kumar et al., 2017; Kumar et al., 2018).

The B.cereus is present in starch rich foods such as rice, nutrient enriched foods of animal origin like meat, milk, dairy products and chicken meat and desserts (Jay, 2005). In India, prevalence of B.cereus has been reported from foods like milk (Garg et al., 1977; Chopra et al., 1980), meat (Bacchil and Negi, 1984; Bacchil and Jaiswal, 1988), chicken (Tahmasebi et al., 2014; Aklilu et al., 2016) and various other foods (Kamat et al., 1989; Meena et al., 2000). Therefore, it is of significant quality food safety issues, medical and economic importance and several methods have been developed for its detection. These methods include a wide range of approaches including but not limited to conventional culture methods (Fricker et al., 2008; Kumar et al., 2011), biochemical and morphological tests (Fernandez-No et al., 2011; Kumar et al., 2009), and a variety of molecular approaches using toxin or other appropriate genes of $B$. cereus group species as target (Kim et al., 2012). Recently, molecular diagnostic tools mainly focus on the toxin genes since they are broadly distributed within the $B$. cereus group (Wehrle et al., 2010) and the toxin gene profiles might be better than the exact species for the outbreak investigations (Ehlingschulz and Messelhausser, 2013) and assessment of toxin genes prevalence in wild $B$. cereus isolates would help controlling these potential pathogens in food industry (McKillip, 2000).

Further more, such assessments would be valuable to determine the genetic diversity of the species leading to a broader ecological view (Oh et al., 2012; Kumar et al., 2014; Kumar et al., 2018). Therefore, there have been some studies investigating the toxigenic diversity of $B$. cereus isolated from different sources. There is restricted information available in comparison to the enterotoxic strains. Accordingly, the reasons of this study became to estimate the virulence pathogenic capacity of $B$. cereus through determining the toxigenic profiles of line strains and investigate the relationship between isolation source and toxigenic profiles, compare toxigenic pattern and compare the results with previous studies to have a better insight on the topic studied.

\section{MATERIALS AND METHODS}

\section{Bacterial strains}

The toxigenic profiling of enterotoxin-producing $B$. cereus strains used in this study were isolated from marketed raw chicken, swabs of human handlers, slaughtering equipments during eleven months (from June-2017 to March-2018) period. A total of 42 strains were isolated from 280 processed samples.

\section{DNA extraction}

All B. cereus strains were grown on nutrient agar (HiMedia Pvt. Ltd.) slants at $37^{\circ} \mathrm{C}$ for $24 \mathrm{hrs}$. A single colony was inoculated in Luria-Bertani broth (HiMedia) and incubated at $37{ }^{\circ} \mathrm{C}$ for $24 \mathrm{hrs}$. After recommended incubation, the total genomic DNA of individual isolates was extracted by using mericon DNA Bacteria plus Kit (Qiagen) according to the manufacturer's instructions with some modification. The quality, purity and concentration of isolated DNA were determined by NanoDrop ${ }^{\mathrm{TM}} 2000 / 2000$ c Spectrophotometers as per methods described by Sambrook and Russel (2001).

\section{Thermal cycling condition and primers}

Table 1: Triplex PCR primers pairs used for the toxigenic profiling of B. cereus

\begin{tabular}{|c|c|c|c|c|}
\hline $\begin{array}{l}\text { Sl. } \\
\text { No. }\end{array}$ & $\begin{array}{l}\text { Target } \\
\text { Genes }\end{array}$ & Primer sequence $\left(5^{\prime} \rightarrow 3^{\prime}\right)$ & $\begin{array}{c}\text { Product } \\
\text { Size }\end{array}$ & Reference \\
\hline 1 & NheB & $\begin{array}{l}\text { F: GTG CAG CAG CTG TAG } \\
\text { GCG GT } \\
\text { R: ATG TTT TTC CAG CTA } \\
\text { TCT TTCGCA AT }\end{array}$ & $328 \mathrm{bp}$ & \\
\hline 2 & HblA & $\begin{array}{l}\text { F: ATT AAT ACA GGG GAT } \\
\text { GGA GAAACT T } \\
\text { R: TGA TCC TAA TAC TTC } \\
\text { TTC TAGACG CTT }\end{array}$ & $237 \mathrm{bp}$ & $\begin{array}{c}\text { (Yang et } \\
\text { al., 2005) }\end{array}$ \\
\hline 3 & HblD & $\begin{array}{l}\text { F: AGA TGC TAC AAG ACT } \\
\text { TCA AAGGGA AAC TAT } \\
\text { R: TGA TTA GCA CGA TCT } \\
\text { GCT TTCATA CTT }\end{array}$ & $436 \mathrm{bp}$ & \\
\hline
\end{tabular}

The primers show in Table 1 was used in triplex PCR study. Triplex PCR was conducted using a thermal cycler (Bio- 
Table 2: Multiplex PCR primers pairs used for the toxigenic profiling of B. cereus

\begin{tabular}{|c|c|c|c|c|}
\hline Sl. No. & Target Genes & $\begin{array}{l}\text { Primer sequence } \\
\quad\left(5^{\prime} \rightarrow 3^{\prime}\right)\end{array}$ & Product Size & Reference \\
\hline \multirow{2}{*}{1} & \multirow{2}{*}{ CytK } & F: TGCTAGTAGTGCTGT AACTC & 881 bp & \multirow{10}{*}{ (Forghani et al., 2014) } \\
\hline & & R: CGTTGTTTCCAAC CCAGT & & \\
\hline \multirow{2}{*}{2} & \multirow{2}{*}{ NheA } & F: GGAGGGGCAAACAGAA GTGAA & 750 bp & \\
\hline & & R: CGAAGAGCTGCTTC TCTCGT & & \\
\hline \multirow{2}{*}{3} & \multirow{2}{*}{ CER } & F: GCGTACCAAATCA CCCGTTC & 546 bp & \\
\hline & & R: TGCAGGTGGCACAC TTGTTA & & \\
\hline \multirow{2}{*}{4} & \multirow{2}{*}{$\mathrm{HblC}$} & F: CGCAACGACAAATC AATGAA & $421 \mathrm{bp}$ & \\
\hline & & R: ATTGCTTCACGAGC TGCTTT & & \\
\hline \multirow{2}{*}{5} & \multirow{2}{*}{ EntFM } & F: AGGCCCAGCTACATA CAACG & $327 \mathrm{bp}$ & \\
\hline & & R: CCACTGCAGTCAAAA CCAGC & & \\
\hline
\end{tabular}

Rad S1000 ${ }^{\mathrm{TM}}$ thermal cycler, Sweden), and amplification conditions were as follows: initial denaturation at $95^{\circ} \mathrm{C}$ for 5 min followed by 30 cycles of denaturation at $95^{\circ} \mathrm{C}$ for $30 \mathrm{sec}$, annealing at $60^{\circ} \mathrm{C}$ for $30 \mathrm{sec}$, extension at $72^{\circ} \mathrm{C}$ for $45 \mathrm{sec}$ and final extension at $72^{\circ} \mathrm{C}$ for $7 \mathrm{~min}$. Each reaction tube $(25 \mu \mathrm{L})$ contained $20 \mathrm{pM}$ of $n h e B$, hblA and $h b l D$ primers, and $6.3 \mathrm{ml}$ nuclease free distilled water and $5 \mathrm{ml}$ of DNA template. Amplified products were electrophoresed on $2 \%$ agarose gel and viewed under UV light and documented by gel documentation system (Bio-Rad Gel Doc ${ }^{\mathrm{TM}}$ XR + Gel Documentation System, Sweden), using Lab image computer software. A $2 \mathrm{ml}$ DNA molecular weight marker (Gene Ruler ${ }^{\mathrm{TM}}$, 100 bp DNA ladder and O GeneRuler100bp Plus DNA Ladder, Thermo Scientific) was used as molecular weight marker.

The primers used in multiplex PCR mention in Table 2. Multiplex PCR was conducted using a thermal cycler (BioRad S1000 ${ }^{\mathrm{TM}}$ thermal cycler, Sweden) and amplification conditions were as follows: initial denaturation at $95^{\circ} \mathrm{C}$ for 10 min followed by 35 cycles of denaturation at $94^{\circ} \mathrm{C}$ for $1 \mathrm{~min}$, annealing at $54^{\circ} \mathrm{C}$ for $1 \mathrm{~min}$, extension at $72^{\circ} \mathrm{C}$ for $1 \mathrm{~min}$ and final extension at $72^{\circ} \mathrm{C}$ for $5 \mathrm{~min}$. Each reaction tube $(25 \mu \mathrm{L})$ contained $20 \mathrm{pM}$ of $c y t K$, nheA, CER, hblC, entFM primers, and $5.5 \mathrm{ml}$ nuclease free distilled water and $5 \mathrm{ml}$ of DNA template and amplified products were electrophoresed same as triplex PCR.

\section{Statistical analysis}

The data obtained was analyzed and expressed as means \pm standard deviations (SD) and compared using chi-square test in IBM ${ }^{\circledR}$ SPSS ${ }^{\circledR}$ software (version 20.0 for Windows, SPSS Inc.) for distribution of toxin genes in $B$. cereus isolated from various sources and their significance of difference was defined at $p \leq 0.05$.

\section{RESULTS AND DISCUSSION}

The $B$. cereus strains investigated in this study isolated from different sources did not reveal the emetic toxinproducing strains. These results were in good agreement with the previous studies (Altayar and Suther, 2006). High prevalence of emetic toxin-producing strains in starchy foods such as rice and rice derived products was reported compared to other food sources (Schoeni and Wong, 2005) and that the emetic toxin-producing strains carry enterotoxin genes (Kim et al., 2009; Kim et al., 2010). The entFM and $n h e B$ were the $1^{\text {st }}$ and $2^{\text {nd }}$ major toxin genes in enterotoxin strains. This result was in good agreement with the reports of Tewari et al. (2015) and Forghani et al. (2014).

All isolates produced $B$. cereus specific PCR product of $400 \mathrm{bp}$ for groEL gene and $475 \mathrm{bp}$ for $g y r B$ gene on Agarose gel (Fig. 1). The isolates were screened by multiplex and triplex PCR for the presence of different enterotoxin genes having the predicted size of 237bp, 436bp, 328bp (by triplex PCR ), 750bp, 421bp, 327bp and 881bp (by multiplex PCR ) for $h b l A, h b l D$, nheB, nhe A, hblC, entFM and $c y t K$, respectively (Fig. 2 and 3 ).

The three nhe (nheA, nheB, nheC) and hbl (hblA, hblC, $h b l D$ ) genes exist in 2 separate operons ensuing the synthesis of the nhe and $h b l$ toxin protein complexes, 
Su

Suthar et al.

Table 3: Different toxigenic gene profiling of total 42 B. cereus isolates

\begin{tabular}{|c|c|c|c|c|c|c|c|c|c|}
\hline Pattern & entFM & nheA & cytK & $C E R$ & hblC & nheB & hblA & $h b l D$ & $\mathrm{Nr}(\%)$ of $\boldsymbol{B}$. cereus Isolates \\
\hline $\mathrm{I}$ & + & + & - & - & + & + & + & + & $9(21.42)$ \\
\hline II & + & + & + & - & + & + & + & + & $4(9.52)$ \\
\hline III & + & - & - & - & + & + & + & + & $4(9.52)$ \\
\hline IV & + & - & - & - & - & + & + & + & $3(7.14)$ \\
\hline $\mathrm{V}$ & + & - & + & - & + & + & + & + & $3(7.14)$ \\
\hline VI & + & - & + & - & - & + & + & + & $2(4.76)$ \\
\hline VII & + & + & - & - & - & - & - & - & $2(4.76)$ \\
\hline VIII & + & - & - & - & - & - & - & - & $2(4.76)$ \\
\hline IX & + & - & - & - & - & + & - & - & $2(4.76)$ \\
\hline $\mathrm{X}$ & + & - & - & - & + & + & + & - & $2(4.76)$ \\
\hline XI & - & - & - & - & - & + & + & - & $1(2.38)$ \\
\hline XII & - & - & - & - & + & + & + & + & $1(2.38)$ \\
\hline XIII & - & + & - & - & + & + & + & + & $1(2.38)$ \\
\hline XIV & + & - & - & - & - & + & + & - & $1(2.38)$ \\
\hline XV & + & + & - & - & + & + & - & + & $1(2.38)$ \\
\hline XVI & + & + & + & - & + & + & + & - & $1(2.38)$ \\
\hline XVII & + & - & - & - & - & - & + & - & $1(2.38)$ \\
\hline XVIII & + & + & - & - & - & - & - & + & $1(2.38)$ \\
\hline XIX & + & + & - & - & - & - & + & - & $1(2.38)$ \\
\hline
\end{tabular}

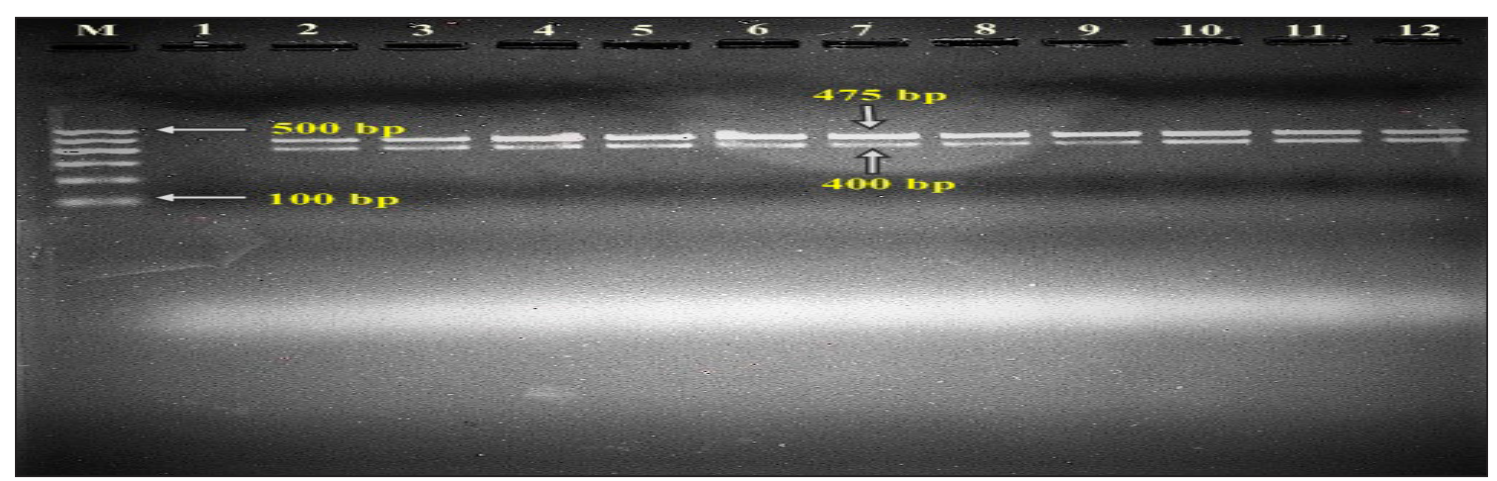

Fig. 1: Agarose gel showing PCR amplified product of 400bp for groEL gene in B. cereus group and 475bp for gyrB gene in B. cereus isolates. Lane M: 100bp DNA ladder, Lane 1: Negative control (Reagent), Lane 2: Positive control (MTCC 25061), Lane 3-12: Isolates of $B$. cereus from chicken meat and human subjects origin

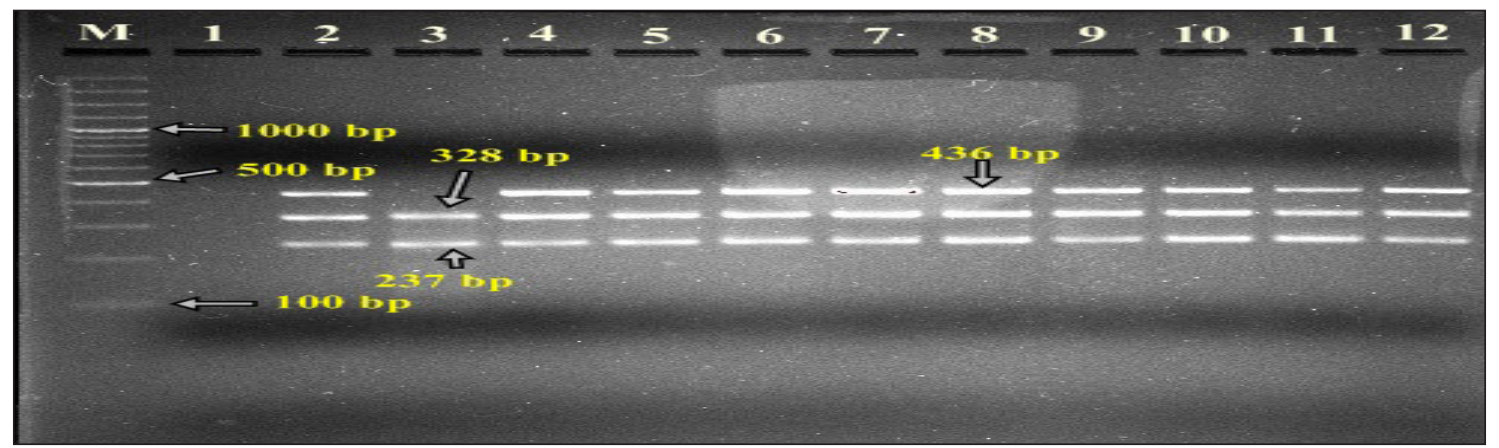

Fig. 2: Agarose gel showing triplex PCR amplified product of $237 \mathrm{bp}$ for $h b l A, 436 \mathrm{bp}$ for $h b l D$, and $328 \mathrm{bp}$ for $n h e B$ gene in $B$. cereus isolates. Lane M: 100bp plus DNA ladder, Lane 1: Negative control (Reagent), Lane 2, 4-12: Samples positive for gene $h b l A, h b l D$ and $n h e B$, Lane 3: Samples positive for $h b l A$ and $n h e B$. 


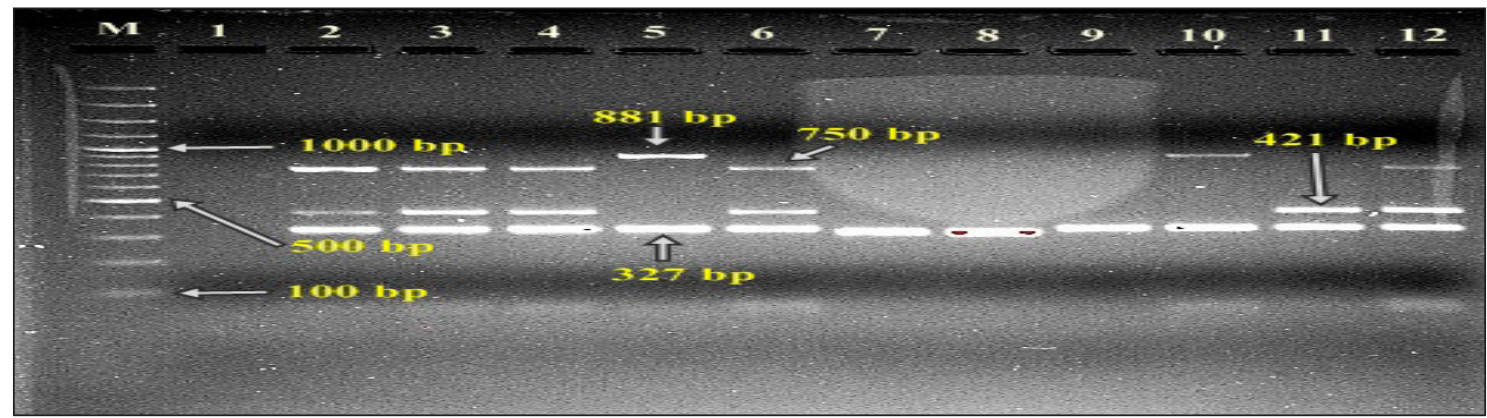

Fig. 3: Agarose gel showing multiplex PCR amplified product of $881 \mathrm{bp}$ for $c y t K, 750 \mathrm{bp}$ for $n h e A, 421 \mathrm{bp}$ for $h b l C$ and $327 \mathrm{bp}$ for entFM gene in B.cereus isolates. Lane M: $100 \mathrm{bp}$ plus DNA ladder, Lane 1: Negative control (Reagent), Lane 2, 3, 4, 6, and 12: Samples positive for $n h e A, h b l C$ and entFM gene, Lane 5, 10: Samples positive for $c y t K$ and entFM gene, Lane 7, 8, 9: Samples positive for entFM gene, Lane 11: Samples positive for $h b l C$ and $e n t F M$ gene

respectively (Granum et al., 1999). However, the presence of all three genes is not essential for the activity of the toxins, however co-presence of other two genes will bring about maximal virulence (Lindback et al., 2004). In addition, the results obtained in the works of Seong et al. (2008), Molva et al. (2009) and Kim et al. (2010) showed that $n h e A, B$ and $C$ as well as $h b l C, D$ and $A$ genes were always present at the same time in the $B$. cereus strains. In another study Ngamwongsatit et al., 2008 reported co existence of $n h e$ and $h b l$ in their respective operons. Based on Rosenquist et al. (2005), Park et al. (2009), Wehrle et al. (2010) and others studies, the best used one out of the three genes of every operon for the detection of nhe or $h b l$ toxin in $B$. cereus strains. As a result, nhe A, nheB, nhe $C$ and $h b l A, h b l C$, hblD genes had been selected from the three general genes of nhe and $h b l$ coding operons, respectively, as a way to put extra effort on investigating a higher wide variety of strains and a numerous pool of isolation resources, which might bring about presenting more useful facts to have a higher perception into $B$. cereus food poisoning.

The distribution of toxic genes among the 42 toxin producing strains $B$. cereus isolates from different sources was divided into 19 different patterns of toxigenic profiles. The pattern I ( 9 strains, $21.42 \%$ ) was found to be the major pattern containing the 6 toxin genes except $C E R$ and $c y t \mathrm{~K}$ followed by pattern II (4 strains, 9.52\%), which contained the entire 7 toxin gene except CER and Pattern III (4 strains, 9.52\%), which carried entFM, hblC, nheB, hblA, and $h b l D$ genes. Four patterns showed the presence of four toxin genes entFM, nheB, hblA, and hblD. Pattern V (3 strains, $7.14 \%$ ) was containing the 6 toxin genes except
nheA and CER. Pattern VI (2 strains, 4.76\%), which contained five toxin genes except nheA, CER and hblC. Pattern VII (2 strains, $4.76 \%$ ), which only possessed two toxin genes entFM and nheA followed by pattern VIII (2 strains, 4.76\%), which carried only entFM gene; all other pattern contained two or more virulence genes. The analyzed toxic gene profiles of all 42 strains of $B$. cereus isolates were presented in Table 3 and in Fig. 4.

Despite the emetic strains, Pattern I (9 strains, 21.42\%) representing the major toxigenic pattern among the enterotoxic strains contained the six enterotoxin genes together except cytK (Table 3). This result was in good agreement with the works of Tewari et al. (2015) and Forghani et al. (2014). The prevalence of single enterotoxin genes was not high among the enterotoxic strains but still more frequent compared to the earlier reported emetic strains (Guinebretiere et al., 2002; Kim et al., 2010; Wehrle et al., 2010).

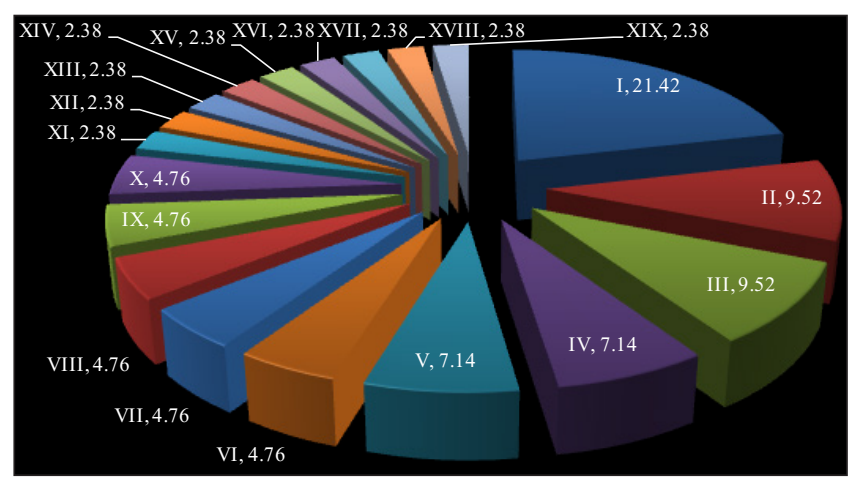

Fig. 4: Pie chart showing toxigenic profiling of amplified potential virulence genes in $42 \mathrm{~B}$. cereus isolates 
Table 4: Summary of toxin genes distribution of Bacillus cereus isolates from raw chicken meat and human subjects

\begin{tabular}{cccccccccccc}
\hline \multirow{2}{*}{$\begin{array}{c}\text { Toxin } \\
\text { gene }\end{array}$} & $\begin{array}{c}\text { Thigh } \\
\text { muscle } \\
\mathbf{n = 8}\end{array}$ & $\begin{array}{c}\text { Breast } \\
\text { muscle } \\
\mathbf{n = 4}\end{array}$ & $\begin{array}{c}\text { Wing } \\
\text { muscle } \\
\mathbf{n = 4}\end{array}$ & $\begin{array}{c}\text { Rib } \\
\text { muscle } \\
\mathbf{n = 2}\end{array}$ & $\begin{array}{c}\text { Neck } \\
\text { muscle } \\
\mathbf{n = 4}\end{array}$ & $\begin{array}{c}\text { Heart } \\
\text { portion } \\
\mathbf{n = 3}\end{array}$ & $\begin{array}{c}\text { Liver } \\
\text { portion } \\
\mathbf{n = 4}\end{array}$ & $\begin{array}{c}\text { Gizzard } \\
\text { portion } \\
\mathbf{n = 1}\end{array}$ & $\begin{array}{c}\text { Chicken } \\
\text { meat } \\
\text { handler n=5 }\end{array}$ & $\begin{array}{c}\text { Butchers- } \\
\text { knife } \\
\mathbf{n}=\mathbf{3}\end{array}$ & $\begin{array}{c}\text { Chopping } \\
\text { board } \\
\mathbf{n}=\mathbf{4}\end{array}$ \\
\hline entFM & $7(87.5 \%)$ & $4(100 \%)$ & $4(100 \%)$ & $2(100 \%)$ & $3(75 \%)$ & $3(100 \%)$ & $4(100 \%)$ & $1(100 \%)$ & $4(80 \%)$ & $3(100 \%)$ & $4(100 \%)$ \\
$n h e A$ & $6(75 \%)$ & $3(75 \%)$ & $\mathrm{ND}$ & $2(100 \%)$ & $3(75 \%)$ & $1(33.33 \%)$ & $1(25 \%)$ & ND & ND & $2(66.66 \%)$ & $2(50 \%)$ \\
$c y t K$ & $4(50 \%)$ & $\mathrm{ND}$ & $1(25 \%)$ & $1(50 \%)$ & $\mathrm{ND}$ & $2(66.66 \%)$ & $1(25 \%)$ & $\mathrm{ND}$ & $\mathrm{ND}$ & $\mathrm{ND}$ & $\mathrm{ND}$ \\
$C E R$ & $\mathrm{ND}$ & $\mathrm{ND}$ & $\mathrm{ND}$ & $\mathrm{ND}$ & $\mathrm{ND}$ & $\mathrm{ND}$ & $\mathrm{ND}$ & $\mathrm{ND}$ & $\mathrm{ND}$ & $\mathrm{ND}$ & $\mathrm{ND}$ \\
$h b l C$ & $6(75 \%)$ & $4(100 \%)$ & $3(75 \%)$ & $2(100 \%)$ & $3(75 \%)$ & $3(100 \%)$ & $3(75 \%)$ & $\mathrm{ND}$ & $2(40 \%)$ & $\mathrm{ND}$ & $1(25 \%)$ \\
$n h e B$ & $8(100 \%)$ & $4(100 \%)$ & $4(100 \%)$ & $2(100 \%)$ & $4(100 \%)$ & $3(100 \%)$ & $4(100 \%)$ & $1(100 \%)$ & $3(60 \%)$ & ND & $2(50 \%)$ \\
$h b l A$ & $8(100 \%)$ & $3(75)$ & $4(100 \%)$ & $2(100 \%)$ & $4(100 \%)$ & $3(100 \%)$ & $3(75 \%)$ & $1(100 \%)$ & $3(60 \%)$ & $1(33.33 \%)$ & $2(50 \%)$ \\
$h b l D$ & $8(100 \%)$ & $4(100 \%)$ & $4(100 \%)$ & $2(100 \%)$ & $3(75 \%)$ & $2(66.66 \%)$ & $2(50 \%)$ & $\mathrm{ND}$ & $2(40 \%)$ & $1(33.33 \%)$ & $1(25 \%)$ \\
$\chi^{2}$ & 33.38 & $25.01 * *$ & $25.60 * *$ & 12.71 & $19.20 * *$ & $14.31 *$ & $15.74 *$ & 08.00 & $15.38 *$ & $14.31 *$ & 12.80 \\
& $(p=1.81)$ & $(p=0.00)$ & $(p=0.00)$ & $(p=0.07)$ & $(p=0.00)$ & $(p=0.04)$ & $(p=0.02)$ & $(p=0.33)$ & $(p=0.03)$ & $(p=0.04)$ & $(p=0.07)$ \\
\hline
\end{tabular}

Note: $* *=$ Highly Significant at $p<0.01, *=$ Significant at $p<0.05, \mathrm{ND}=$ Not detected, $\mathrm{n}=$ No. of positive sample, $\chi^{2}=$ Chi-Square, $p=$ Probability value, $\%=$ Percentage.

Tewari et al., 2013). The high variety of toxigenic profiles among strains reconfirmed the progressive emergence of novel toxin gene profiles, confronting food industry and food microbiology laboratories with novel hazards (Thorsen et al., 2006; Chon et al., 2012; Ehling-schulz and Messelhausser, 2013).

The summarized the distribution of enterotoxin genes in $B$. cereus isolated from various sources and their significance of difference in Pearson Chi-Square is $(p<0.05)$ describe in Table 4. The results indicated that entFM was the most prevalent potent enterotoxin gene regardless of the isolation bacterium with a prevalence of $75 \%$ to $100 \%$. The second most frequent enterotoxin gene among all bacterium was $n h e B$, showing the highest prevalence in all samples wise raw chicken meat isolates (100\%) and the lowest in swab sample of chopping board isolated strains (50\%). It was also more prevalent than the other enterotoxin genes (nheA, cytK and $h b l C$ ) in every individual sample wise raw chicken meat isolated bacterium. The nhe A, cytK and hblC genes showed a much higher range of diversity in their prevalence among different isolation as compared to the 3 afore mentioned enterotoxin genes (nheB, hblA and $h b l D)$. The $n h e A$ gene showed a similar prevalence of more than $50 \%$ in swab samples isolates from chopping board and butchers knife, thigh muscle, breast muscle, rib muscle, neck muscle, while its prevalence was as low as $25 \%$ in liver portion isolates. A similar phenomenon was observed for $c y t K$ gene being present in only $25 \%$ of liver portion samples isolates and wing muscle, while it showed a much higher prevalence of $66.66 \%$ in heart portion and $50 \%$ in thigh muscle and rib muscle bacterium. The $h b l C$ gene showed more than $75 \%$ prevalence in thigh muscle, breast muscle, wing muscle, rib muscle, neck muscle, heart portion and liver portion isolates, while its prevalence was as low as $40 \%$ and $25 \%$ in human hand swab and swab of chopping board isolated bacterium, respectively. The CER emetic gene was not detected in all the isolates.

The entFM was always the most prevailing toxin gene among all strains, regardless of isolation source. This result was in good agreement with numerous previous studies (Tewari et al., 2015; Forghani et al., 2014). The $n$ he genes are widely accepted as the most frequent enterotoxin genes and their presence with a lower frequency than any other enterotoxin has rarely been reported (MartınezBlanch et al., 2009). In present study the nheB gene was the 2nd major gene among strains and showed a much higher prevalence among the enterotoxin-producing strains (Table 3 ). The $h b l A$ and $h b l D$ were the $3^{\text {rd }}$ and $4^{\text {th }}$ prevailing genes, respectively.

The presence of entFM as the major enterotoxin after $n$ he (Ngamwongsatit et al., 2008; Seong et al., 2008; Kim et al., 2009; Tewari et al., 2013) has previously been reported. However, Park et al. (2009) and Kim et al. (2011) reported $h b l$ as the 2nd major enterotoxin with $84 \%$ and 
90\% prevalence, respectively. The findings in this study as well as a few more recent reports suggest that entFM, Nhe, $\mathrm{Hbl}$ and $\mathrm{CytK}$ which is implicated in adhesion, biofilm formation, and virulence (Tran et al.,2010) should be considered as a main enterotoxin in $B$. cereus.

\section{CONCLUSION}

In conclusion, results obtained in the present study revealed that $B$. cereus might be a serious health hazard due to its ubiquity, high prevalence of pathogenic strains and that they may harbor toxin genes regardless of their origin. The entFM and $n h e B$ genes were the major enterotoxin genes found among a high number of $B$. cereus strains. Present study investigated a wider range of $B$. cereus sources leading to a broader insight on the matter. Isolates from different sources occasionally showed different patterns of gene prevalence. Also, future studies may identify strains up to species level followed by toxigenic profiling in order to investigate the relationship between species type and pathogenic potential.

\section{ACKNOWLEDGMENTS}

The authors are grateful to the Dean, College of Veterinary science \& Animal Husbandry and Director of Research, Navsari Agricultural University. Navsari-396 450, Gujarat, India for providing necessary facility and resources to conduct this study.

\section{REFERENCES}

Aklilu, E., Tukimin, E.B.,Daud, N.B.A. and Kyaw, T. 2016. Enterotoxigenic Bacillus cereus from cooked chicken meat: a potential public health hazard. Malaysian J. Microbiol., 12(1): 112-115.

Altayar, M. and Suther, A.D. 2006. Bacillus cereus is common in the environment but emetic toxin producing isolates are rare. J. App. Microbiol., 100(1): 7-14.

Bachhil, V.N. and Jaiswal, T.N. 1988. Bacillus cereus in meats: incidence, prevalence and enterotoxigenicity. J. Food Sci. Tech., 25(6): 371-372.

Bachhil, V.N. and Negi, S.K. 1984. Bacillus cereus in meat and meat products: public health implications and control. Indian J. Public Health, 28(2):68-69.

Chon, J.W., Kim, J.H., Lee, S.J., Hyeon, J.Y. and Seo, K.H. 2012. Toxin profile, antibiotic resistance, and phenotypic and molecular characterization of Bacillus cereus in Sunsik. Food Microbiol., 32(1): 217-222.
Chopra, P., Singh, A. and Kalra, M.S. 1980. Occurrence of Bacillus cereus in milk and milk products. Indian J. Dairy Sci., 33(2): 248-252.

Ehling-Schulz, M. and Messelhausser, U. 2013. Bacillus "next generation" diagnostics: moving from detection toward subtyping and risk-related strain profiling. Fron. Microbiol., 4(32):1-8.

Fernandez-No, I.C., Guarddon, M., Bohme, K., Cepeda, A., Calo-Mata, P. and Barros Velazquez, J. 2011. Detection and quantification of spoilage and pathogenic Bacillus cereus, Bacillus subtilis and Bacillus licheniformis by real-time PCR. Food Microbiol., 28(3): 605-610.

Forghani, F., Kim, J.B. and Oh, D.H. 2014. Enterotoxigenic Profiling of Emetic Toxin- and Enterotoxin- Producing Bacillus cereus, Isolated from Food, Environmental, and Clinical Samples by Multiplex PCR. J. Food Sci., 79(11): M2288-M2293.

Fricker, M., Reissbrodt, R. and Ehling Schulz, M. 2008. Evaluation of standard and new chromogenic selective plating media for isolation and identification of Bacillus cereus. Int. J. Food Microbiol.,121(1): 27-34.

Garg, D.N., Bhargava, D.N. and Narayan, K.G. 1977. Pathogenic bacterial flora of raw market milk. Indian J. Dairy Sci., 30(1): 36-39.

Granum, PE., O'sullivan, K. and Lund, T. 1999. The sequence of the non-haemolytic enterotoxin operon from Bacillus cereus. FEMS Micro. Lett., 177(2): 225-229.

Guinebretière, M.H. and Broussolle, V. 2002. Enterotoxigenic profiles of food-poisoning and foodborne Bacillus cereus strains. J. Clin. Microbiol., 40(8): 3053-3056.

Helgason, E., Okstad, O.A., Caugant, D.A., Johansen, H.A., Fouet, A., Mock, M. and Kolsto, A.B. 2000. Bacillus anthracis, Bacillus cereus, and Bacillus thuringiens is one species on the basis of genetic evidence. Appl. Environ. Microbiol., 66(6): 2627-2630.

Jay, J.M. 2005. Modern Food Microbiology. 4th ed. CBS Publishers \& Distributors Pvt. Ltd, pp. 501-503.

Jimenez, G., Blanch, A.R., Tamames, J. and Rossello Mora, R. 2013. Complete genome sequence of Bacillus toyonensis BCT-7112T, the active ingredient of the feed additive preparation Toyocerin. Gen. Announc., 1(6):e01080-13.

Kamat, A.S., Nerkar, D.P. and Nair, P.M. 1989. Bacillus cereus in some Indian foods, incidence and antibiotic, heat and radiation resistance. J. Food Safety, 10(1): 31-41.

Kim, J.B., Kim, J.M., Cho, S.H., Oh, H.S., Choi. N.J. and Oh, D.H. 2011. Toxin genes profiles and toxin production ability of Bacillus cereus isolated from clinical and food samples. $J$. Food Sci., 76(1): 25-29. 
Kim, J.B., Kim, J.M., Kim, C.H., Seo, K.S., Park, Y.B., Choi, N.J. and Oh, D.H. 2010. Emetic toxin producing Bacillus cereus Korean isolates contain genes encoding diarrhealrelated enterotoxins. In. J. Food Microbiol., 144(1): 182-186.

Kim, J.M., Forghani, F., Kim, J.B., Park, Y.B., Park, M.S., Wang, J. and Oh, D.H. 2012. Improved multiplex PCR assay for simultaneous detection of Bacillus cereus emetic and enterotoxic strains. Food Sci. Biotech., 21(5): 1439-1444.

Kim, S.K., Kim, K., Jang, S.S., Shin, E.M., Kim, M.J., Oh, S. and Ryu, S. 2009. Prevalence and toxigenic profiles of Bacillus cereus isolated from dried red peppers, rice, and Sunsik in Korea. J. Food Pro., 72(3): 578-582.

Kramer, J.M. and Gilbert, R.J. 1989. Bacillus cereus and other Bacillus species. Foodborne Bacterial Pathogens, 19: 21-70.

Kumar, R. and Singh, S.P. 2014. Pulse field Gel electrophoresisprofiles of salmonella enteric serovar typhimurium isolates obtained from chickens sources. Indian J. Comp. Microbiol. Immunol. Infect. Dis., 35(2): 64-66.

Kumar, R., Dutta, S. and Pal, D. 2017. Microbiological quality assessment and detection of fecal Escherichia coli (coliform) in foods of animal origin sold in the open markets of Kolkata city in India. Indian J. Comp. Microbiol. Immunol. Infect. Dis., 38(1): 22-25.

Kumar, R., Prasad, A. and Singh, S.P. 2009. Modern trends to investigate Salmonella in foods. J. Anim. Vet. Adv., 8(9): 1723-1728.

Kumar, R., Prasad, A., Kumar, P. and Shukla, S.K. 2011. Isolation and identification of salmonella from chicken samples by polymerase chain reaction. Indian J. Poultry Sci., 46(2): 261-264.

Kumar, R., Singh, S.P., Kumar, M. and Kumar, A. 2018. Determination of Low Molecular weight Immunogenic Omp28 Protein and Gene of Salmonella typhimurium. South Asian J. Exp. Biol., 8(5): 172-177.

Ladeuze, S., Lentz, N., Delbrassinne, L., Hu, X. and Mahillon, J. 2011. Antifungal activity displayed by cereulide, the emetic toxin produced by Bacillus cereus. Appl. Environ. Microbiol., 77(7): 2555-2558.

Lindback, T., Fagerlund, A., Rodland, M.S. and Granum, P.E. 2004. Characterization of the Bacillus cereus Nhe enterotoxin. Microbiology., 150(12): 3959-3967.

Martinez Blanch, J.F., Sanchez, G., Garay, E. and Aznar, R. 2009. Development of a real-time PCR assay for detection and quantification of enterotoxigenic members of Bacillus cereus group in food samples. Int. J. Food Microbiol., 135(1): $15-21$.

McKillip, J.L. 2000. Prevalence and expression of enterotoxins in Bacillus cereus and other Bacillus spp., a literature review. Antonie Van Leeuwenhoek., 77(4): 393-399.
Meena, B.S., Kapoor, K.N. and Agarwal, R.K. 2000. Occurrence of multi-drug resistant Bacillus cereus in foods. J. Food Sci. Tech., 37(3):289-291.

Molva, C., Sudagidan, M. and Okuklu, B. 2009. Extracellular enzyme production and enterotoxigenic gene profiles of Bacillus cereus and Bacillus thuringiensis strains isolated from cheese in Turkey. Food Cont., 20(9): 829-834.

Ngamwongsatit, P., Buasri, W., Pianariyanon, P., Pulsrikarn, C., Ohba, M., Assavanig, A. and Panbangred, W. 2008. Broad distribution of enterotoxin genes ( $h b l C D A$, nhe $A B C$, cytK, and entFM) among Bacillus thuringiensis and Bacillus cereus as shown by novel primers. Int. J. Food Microbiol., 121(3): 352-356.

Oh, M.H., Ham., J.S. and Cox, J.M. 2012. Diversity and toxigenicity among members of the Bacillus cereus group. Int. J. Food Microbiol., 152(1-2): 1-8.

Park, Y.B., Kim, J.B., Shin, S.W., Kim, J.C., Cho, S.H., Lee, B.K. and Oh, D.H. 2009. Prevalence, genetic diversity, and antibiotic susceptibility of Bacillus cereus strains isolated from rice and cereals collected in Korea. J. Food Pro.,72(3): 612-617.

Rosenquist, H., Smidt, L., Andersen, S.R., Jensen, G.B. and Wilcks, A. 2005. Occurrence and significance of Bacillus cereus and Bacillus thuringiensis in ready-to-eat food. FEMS Microbiol. Lett., 250(1): 129-136.

Sambrook, J. and Russell, D.W. 2001. Molecular cloning: A Laboratory Mannual, $3^{\text {rd }}$ eds. Cold Spring Harbor Laboratory Press, Cold Spring Harbor, NY, USA.

Sandra, A., AfsahHejri, L., Robin, T., Chilek, T., Zainazor, T., Tang, J.Y.H. and Radu, S. 2012. Bacillus cereus and Bacillus thuringiensis in ready-to-eat cooked rice in Malaysia. Int. Food Res. J., 19(3): 829- 836.

Schoeni, J.L. and LeeWong, A.C. 2005. Bacillus cereus food poisoning and its toxins. J. Food Pro., 68(3): 636-648.

Seong, S.J., Lim, J.S., Lee, K.G., Lee, S.J. and Hong, K.W. 2008. Toxin gene profiling of Bacillus cereus food isolates by PCR. J. the Korean Soc. for App. Bio. Chem., 51(4): 263-8.

Tahmasebi, H., Talebi, R. and Zarif, B.R. 2014. Isolated of Bacillus cereus in Chicken Meat and Investigation $\beta$-Lactamase antibiotic-resistant in Bacillus cereus from Chicken Meat. Adva. Life Sci., 4(4): 200-206.

Tewari, A. and Singh, S.P. 2015. Incidence and Enterotoxin Gene Profile of Bacillus cereus Strains Isolated from Human Stool Samples from Uttarakhand, India. J. Pure Appl. Microbiol., 9(1): 285-291

Tewari, A., Singh, S.P. and Singh, R. 2013. Incidence and enterotoxigenic profile of Bacillus cereus in meat and meat products of Uttarakhand, India. J. Food Sci. Tech., 52(3): 1796-1801. 
Thorsen, L., Hansen, B.M., Nielsen, K.F., Hendriksen, N.B., Phipps, R.K. and Budde, B.B. 2006. Characterization of emetic Bacillus weihenstephanensis, a new cereulideproducing bacterium. Appl. Environ. Microbiol., 72(7): 51185121.

Tran, S.L., Guillemet, E., Gohar, M., Lereclus, D. and Ramarao, N. 2010. CwpFM (entFM) is a Bacillus cereus potential cell wall peptidase implicated in adhesion, biofilm formation, and virulence. J. Bact., 192(10): 2638-2642.
Wehrle, E., Didier, A., Moravek, M., Dietrich, R. and Martlbauer, E. 2010. Detection of Bacillus cereus with enteropathogenic potential by multiplex real-time PCR based on SYBR green I. Mole. Cell. Probes., 24(3): 124-130.

Yang, I., Shih, D.Y.C., Huang, T.P., Huang, Y.P., Wang, J.Y. and Pan, T.M. 2005. Establishment of a novel multiplex PCR assay and detection of toxigenic strains of the species in the Bacillus cereus group. J. Food Pro., 68(10): 2123-2130. 
